\title{
EVALUATION OF AWASSI SHEEP GENOTYPES FOR GROWTH, MILK PRODUCTION AND MILK COMPOSITION
}

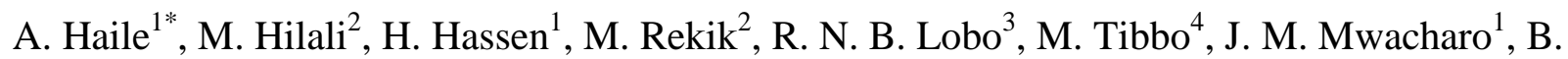 \\ Rischkowsky ${ }^{1}$ \\ ${ }^{1}$ International Centre for Agricultural Research in the Dry Areas (ICARDA), c/o ILRI 5689 Addis Ababa, Ethiopia; \\ ${ }^{2}$ ICARDA, P.O. Box, 950764 Amman 11195, Jordan; \\ ${ }^{3}$ Embrapa Caprinos e Ovinos, Caixa Postal 71, CEP 62010-970, Sobral/CE, Brazil; \\ ${ }^{4}$ FAO, Regional Office for the Near East and North Africa, Dokki 12311, Cairo, Egypt.
}

Received - April 12, 2017; Revision - May 03, 2017; Accepted - May 05, 2017

Available Online - August 31, 2017

DOI: http://dx.doi.org/10.18006/2017.5(Spl-1-SAFSAW).S68.S75

\section{KEYWORDS}

Sheep

Awassi genotype

Growth

Milk traits

\begin{abstract}
We evaluated growth, milk production and composition of Awassi genotypes based on 9 years data collected from the International Center for Agricultural Research in the Dry Areas (ICARDA) flock kept in Tal Hadya station, Syria (now moved to Terbol station, Lebanon). Performances of the pure genotypes (Syrian and Turkish Awassi) and the resulting crosses were compared. Growth performances did not differ among the genetic groups except for weaning weight, for which the Turkish Awassi was lighter than the Syrian Awassi and all its crosses; the 75\% Syrian genotype being the heaviest $(19.54 \pm 0.43 \mathrm{~kg})$. Genetic groups did not differ $(p>0.05)$ for both lactation length (overall mean $100.39 \pm 1.20$ days) and lactation milk yield (overall mean $91.2 \pm 2.50 \mathrm{~kg}$ ). Lactation yields of milk constituents (fat, protein, lactose, total solids and solids-not-fat) were, however, higher for the $75 \%$ Syrian crosses compared to the other crosses as well as to the pure Awassi sheep, except for lactation protein yield. The performances of Turkish Awassi were not superior to those of the Syrian genotype for all the traits considered under the environmental conditions of Syria. It is concluded that the Turkish Awassi should not be used as an improver breed for the Syrian genotype. The performance of the ICARDA maintained Awassi flock has on average been better compared to those of other farms in the region. Improved rams produced from the breeding program could therefore serve as improver for flocks maintained in countries of the region, necessitating the development of appropriate delivery systems of improved genetics.
\end{abstract}

* Corresponding author

E-mail: a.haile@cgiar.org (Aynalem Haile)

Peer review under responsibility of Journal of Experimental Biology and Agricultural Sciences.

Production and Hosting by Horizon Publisher India [HPI] (http://www.horizonpublisherindia.in/).

All rights reserved.
All the article published by Journal of Experimental Biology and Agricultural Sciences is licensed under a Creative Commons Attribution-NonCommercial 4.0 International License Based on a work at www.jebas.org. 


\section{Introduction}

Indigenous to West Asia, Awassi sheep excel in milk and meat production, and are an important component in the livelihoods of many resource-poor farmers across the Middle East (Talafha \& Ababneh, 2011). Moreover, Awassi sheep have been exported from their original home tract in east of the Mediterranean to more than 30 countries in all continents (Galal et al., 2008). As a result, Awassi sheep has been identified as an international transboundary breed by FAO (2015). The Awassi evolved as a nomadic sheep breed through centuries of natural and selective breeding and became the highest milk producing autochthonous breed in the Middle East. This breed is calm around people, easy to work with and easily milked. The breed also has the advantage of natural hardiness, grazing ability and it is well suited to a grazing production system as well as a confined management. The largest population, 18 million head, was found in Syria in 2011 but this number has declined by 40 percent (to 10.8 million) in 2015 due to the civil strife (CFSAM, unpublished). The breed is also found in Lebanon, Jordan, Palestine, Iraq, Iran and Turkey. Promising market prices and increased demand on animal products are leading to intensified production systems aimed at increasing milk and meat yields. Independent reports (Galal et al., 2008; Iñiguez \& Hilali, 2009) in North African and West Asian countries have identified limited access to improved animals as barrier to improved production. Very few existing breeding programs have the potential to address this demand in the region. Two such programs include the Al-Kraim breeding program under the Ministry of Agriculture in Salamieh, Syria (Kassem, 2005) and the Ceylanpinar program in Turkey (Gürsoy, 2005). Other less well-structured programs are taking place in (i) Jordan, using the state-owned flock in Msharfeh and Khanassri stations and (ii) Lebanon, based on the flock of the Lebanese Agricultural Research Institute (LARI).

In response to farmers' demand for improved animals, ICARDA set up a breeding program aimed at improving milk and meat production potential of Awassi sheep, with a view to a wider use of improved rams through natural mating and artificial insemination. Part of this initiative involved comparing the performance of different Awassi lines. Given that Awassi has been distributed to different countries and the fact that different lines have been developed suiting specific production systems, it is expected that improved superior line found in one location could be used to jump start breeding programs in other location. For this purpose the performance of pure Syrian Awassi, Turkish Awassi (believed to be more productive than Syrian Awassi) and crosses between the two lines were evaluated at a specific site. This paper reports on growth, milk production and milk composition performance of Awassi genotypes and its crosses.

\section{Materials and Methods}

\subsection{Description of the experimental location and genotypes}

Data for the study were collected from an experimental sheep flock that was maintained at ICARDA's Tal Hadya station, Aleppo, Syria. Formed by 1980, the foundation of ICARDA's experimental Syrian Awassi (S) flock is a group of ewes that originated in the steppes of Syria. In 1986, the flock was expanded by incorporating ewes from the Aleppo region (Syria). The founding groups, which represented a random sample of the local population of Syrian Awassi, were not subjected to any selection plan, other than farmers' regular breeding practices. Rams from the Syrian governments' Al-Kraim breeding program were used as sires for the $\mathrm{S}$ flock. Thereafter, only these rams or their progeny born in the flock were used as sires. As a result, the $S$ genotype in this study carries genes from rams sourced from the Al-Kraim program. In 1991, ICARDA acquired improved Awassi sheep of the Ceylanpinar Turkish genotype (T). In 1998, a few T ewes bred at ICARDA were inseminated with fresh semen from Ceylanpinar $\mathrm{T}$ rams $(\mathrm{n}=21)$. The $\mathrm{S}$ and $\mathrm{T}$ flocks at ICARDA were kept pure and mated at random without consideration for milk production potential. During the breeding season of 1999, in addition to continuing to breed the pure $\mathrm{S}$ and $\mathrm{T}$ flocks, $\mathrm{T}$ rams were mated to $\mathrm{S}$ ewes to produce $\mathrm{F} 1$ crosses. The offspring of the crosses, genotype TS, were born from the year 2000 onwards. Nine years (2003-2011) of data were used for this study.

\subsection{Flock management practices}

All animals were reared under similar conditions at the ICARDA experimental research station in Tal Hadya, Syria. Animals were allowed to be mated in August each year after a period of separation of at least 4 weeks between the ewes and the rams. The lambs were weaned at $56 \pm 3$ days after parturition and ewes were milked until daily milk yield per ewe fell below $200 \mathrm{ml}$ during a single day. During lactation season, animals were allowed to graze on range after morning milking from 7:00 to 13:30. In late May and June, ewes were allowed to graze on stubbles for 1 hour before grazing on natural rangeland. Ewes are machine milked at 06.00 $\mathrm{h}$ and 17:00 $\mathrm{h}$ every day. The animals are shorn once a year during spring season (April - May).

The ewes were offered a supplement four weeks prior to lambing and throughout lactation to provide 220 g/ewe/day of crude protein (CP) and 18.1 MJ of metabolizable energy (ME)/ewe/day. The supplement is divided into 2 meals at 13:30 and 18:00. During the 2003 and 2004 milking seasons, variation in yield led to the targeted end-of-season culling of ewes producing less than $70 \mathrm{~kg}$ of milk. In 2005, the culling threshold was raised to $100 \mathrm{~kg}$ of milk. All the animals were regularly (every 6 months) drenched against internal parasites and were subjected to the following vaccination calendar: Enterotoxaemia and Pasteurellosis in October-November, Anthrax in May-June, Foot and mouth 
diseases in September, Brucellosis in May-June and Sheep pox in August.

\subsection{Variables recorded}

Milk production per ewe was recorded weekly after weaning until the end of lactation, when ewes produced $\leq 150 \mathrm{~g}$ per day. Beginning 2003, ewes were milked twice daily. Milk production between consecutive control days was estimated and summed to obtain the total milk yields ( $\mathrm{kg}$ ), along with milking length (days). Milk samples collected on control days (pooled over the daily milkings) were analyzed for protein, fat and solids not-fat ( $\mathrm{SnF}$ ) content, using a Milkoscan 133B device (Foss Electric Hillerød, Denmark). Several additional variables were recorded for both lambs and ewes. Overall, the traits studied were: birth weight (BWT), weaning weight (WWT), litter weight at birth (LWB), litter weight at weaning (LWW), lactation length (LL), lactation milk yield (LMY), daily milk yield (DMY), lactation fat, protein, lactose, total solids and $\mathrm{SnF}$ yields.

\subsection{Data analysis}

Table 1 shows the total number of records that were available for the analysis after editing. Data were analyzed using the MIXED PROCEDURE of the Statistical Analysis Systems Institute (SAS, 2002). The fixed effects fitted were: genotype (5 classes: Syrian Awassi, Turkish Awassi, 50\% Syrian-Turkish, 75\% Syrian-25\% Turkish and 75\% Turkish-25\% Syrian blood levels); birth/lambing year (9 classes: 2003 to 2011); sex (two classes: male and female); litter size (2 classes: single and multiple); and parity ( 5 classes: $1^{\text {st }}$ to $5^{\text {th }}$ and above). Sire effect was fitted as random effect. Thus, a mixed effect model was fitted. Two-way interactions of effects were also fitted in the models and retained in the final model when found significant $(\mathrm{p}<0.05)$ in the preliminary analysis. However, results were not presented in this paper. Tukey-Kramer test was used to separate least squares means with more than two levels.

\section{Results and Discussion}

\subsection{Genotype comparisons}

Performance of the Awassi breed and its 'crosses' varies according to production environment and strain; the synthetic Israeli improved Awassi being the heaviest, the most prolific and the highest milk producer (Galal et al., 2008). Efforts to improve the performance of Awassi genotypes yielded good results in few countries (Gürsoy et al., 1995; Galal et al., 2008; Milan et al., 2011). An improved Turkish Awassi was introduced for 'crossbreeding' to improve Syrian Awassi in Tal Hadya ICARDA station and different combinations of crossbreds were produced. We intend to report the performance of the different genotypes and effect of fixed variables on performance of the flock for future management decisions.

\subsection{Growth performance}

Differences between genetic groups in growth performance traits were not significant except for weaning weight $(\mathrm{p}<0.01$; Table 2$)$. For this latter trait, the Turkish Awassi genotype was lighter $(17.79 \pm 0.38 \mathrm{~kg})$ than the Syrian Awassi $(18.37 \pm 0.27)$ and all its

Table 1 Number of records used for the analysis

\begin{tabular}{|l|c|c|c|c|c|}
\hline \multicolumn{1}{|c|}{ Traits } & \multicolumn{5}{c|}{ Genetic group } \\
\cline { 2 - 7 } Birth weight & Syrian Awassi & Turkish Awassi & $50 \%$ cross & $75 \%$ Syrian & $75 \%$ Turkish \\
\hline Weaning weight & 1143 & 176 & 492 & 33 & 147 \\
\hline Litter weight at birth & 990 & 159 & 448 & 31 & 140 \\
\hline Litter weight at weaning & 1142 & 176 & 492 & 33 & 147 \\
\hline Lactation length & 1011 & 165 & 462 & 32 & 143 \\
\hline Lactation milk yield & 724 & 173 & 378 & 45 & 172 \\
\hline Daily milk yield & 674 & 164 & 362 & 44 & 172 \\
\hline Lactation fat yield & 724 & 173 & 378 & 45 & 172 \\
\hline Lactation protein yield & 724 & 173 & 378 & 45 & 172 \\
\hline Lactation lactose yield & 724 & 173 & 378 & 45 & 172 \\
\hline Lactation total solids yield & 724 & 173 & 378 & 45 & 172 \\
\hline Lactation solids-not fat yield & 724 & 173 & 378 & 45 & 172 \\
\hline
\end{tabular}

Journal of Experimental Biology and Agriculture Science http://www.jebas.org 
Table 2 Least squares means ( \pm SE) for effects of sex, litter size at birth, litter size at weaning, year, genetic group and parity of ewe on birth weight, weaning weight, litter weight at birth and litter weight at weaning

\begin{tabular}{|c|c|c|c|c|}
\hline Effect and level & Birth weight $(\mathrm{kg})$ & $\begin{array}{r}\text { Weaning weight } \\
(\mathrm{kg})\end{array}$ & $\begin{array}{r}\text { Litter weight at birth } \\
(\mathrm{kg})\end{array}$ & $\begin{array}{r}\text { Litter weight at weaning } \\
(\mathrm{kg})\end{array}$ \\
\hline $\mathrm{N}$ & 1731 & 1576 & 1731 & 1603 \\
\hline Overall & $4.39 \pm 0.03$ & $18.5 \pm 0.21$ & $6.4 \pm 0.04$ & $26.1 \pm 0.26$ \\
\hline Sex & $* *$ & $* *$ & $* *$ & ** \\
\hline Female & $4.30 \pm 0.04$ & $17.9 \pm 0.23$ & $6.5 \pm 0.06$ & $25.5 \pm 0.28$ \\
\hline Male & $4.47 \pm 0.04$ & $19.1 \pm 0.23$ & $6.3 \pm 0.05$ & $26.8 \pm 0.28$ \\
\hline LSB & $* *$ & $* *$ & $* *$ & $* *$ \\
\hline Single & $4.84 \pm 0.03$ & $19.9 \pm 0.35$ & $4.9 \pm 0.04$ & $27.5 \pm 0.38$ \\
\hline Multiple & $3.93 \pm 0.04$ & $17.1 \pm 0.33$ & $7.9 \pm 0.05$ & $24.8 \pm 0.36$ \\
\hline LSW & NA & $* *$ & NA & $* *$ \\
\hline Single & & $19.7 \pm 0.32$ & & $19.5 \pm 0.35$ \\
\hline Multiple & & $17.2 \pm 0.37$ & & $32.7 \pm 0.41$ \\
\hline Year & $* *$ & $* *$ & $* *$ & ** \\
\hline 2003 & $4.34 \pm 0.07$ & $17.1 \pm 0.43$ & $6.2 \pm 0.08$ & $24.1 \pm 0.52$ \\
\hline 2004 & $4.19 \pm 0.12$ & $18.4 \pm 0.83$ & $6.1 \pm 0.16$ & $25.3 \pm 0.99$ \\
\hline 2005 & $4.26 \pm 0.05$ & $18.5 \pm 0.35$ & $6.3 \pm 0.07$ & $26.5 \pm 0.43$ \\
\hline 2006 & $4.41 \pm 0.05$ & $18.2 \pm 0.33$ & $6.4 \pm 0.07$ & $25.6 \pm 0.41$ \\
\hline 2007 & $4.60 \pm 0.06$ & $17.6 \pm 0.39$ & $6.7 \pm 0.08$ & $25.0 \pm 0.48$ \\
\hline 2008 & $4.40 \pm 0.05$ & $18.8 \pm 0.33$ & $6.4 \pm 0.07$ & $26.8 \pm 0.41$ \\
\hline 2009 & $4.44 \pm 0.05$ & $18.8 \pm 0.32$ & $6.4 \pm 0.07$ & $26.9 \pm 0.40$ \\
\hline 2010 & $4.45 \pm 0.06$ & $20.5 \pm 0.38$ & $6.5 \pm 0.08$ & $29.0 \pm 0.47$ \\
\hline Genetic group & NS & $* *$ & NS & NS \\
\hline Syrian Awassi & $4.35 \pm 0.04$ & $18.4 \pm 0.27^{\mathrm{a}}$ & $6.3 \pm 0.05$ & $26.0 \pm 0.33$ \\
\hline Turkish Awassi & $4.35 \pm 0.06$ & $17.8 \pm 0.38^{\mathrm{a}}$ & $6.3 \pm 0.08$ & $25.5 \pm 0.47$ \\
\hline $50 \%$ Cross & $4.46 \pm 0.04$ & $18.4 \pm 0.29^{\mathrm{a}}$ & $6.4 \pm 0.06$ & $25.8 \pm 0.35$ \\
\hline $75 \%$ Syrian & $4.40 \pm 0.07$ & $19.5 \pm 0.43^{b}$ & $6.4 \pm 0.09$ & $27.1 \pm 0.52$ \\
\hline 75\% Turkish & $4.37 \pm 0.05$ & $18.4 \pm 0.30^{\mathrm{a}}$ & $6.4 \pm 0.06$ & $26.2 \pm 0.38$ \\
\hline Parity & $* *$ & $* *$ & $* *$ & ** \\
\hline 1 & $4.21 \pm 0.04^{\mathrm{a}}$ & $17.7 \pm 0.28^{\mathrm{a}}$ & $6.1 \pm 0.05^{\mathrm{a}}$ & $25.4 \pm 0.34^{\mathrm{a}}$ \\
\hline 2 & $4.39 \pm 0.04^{b}$ & $18.8 \pm 0.28^{b}$ & $6.3 \pm 0.05^{\mathrm{b}}$ & $26.5 \pm 0.34^{\mathrm{b}}$ \\
\hline 3 & $4.46 \pm 0.05^{\mathrm{bc}}$ & $18.5 \pm 0.31^{b}$ & $6.5 \pm 0.06^{\mathrm{cd}}$ & $26.0 \pm 0.38^{\mathrm{a}}$ \\
\hline 4 & $4.38 \pm 0.06^{\mathrm{bc}}$ & $18.5 \pm 0.39^{\mathrm{b}}$ & $6.4 \pm 0.08^{\mathrm{bd}}$ & $25.9 \pm 0.47^{\mathrm{a}}$ \\
\hline 5 & $4.49 \pm 0.05^{\mathrm{c}}$ & $19.0 \pm 0.30^{\mathrm{b}}$ & $6.5 \pm 0.06^{\text {cd }}$ & $26.9 \pm 0.36^{b}$ \\
\hline
\end{tabular}

crosses $(18.36 \pm 0.29,19.54 \pm 0.43,18.38 \pm 0.30 \mathrm{~kg}$ for $50 \%$ Cross, $75 \%$ Syrian and $75 \%$ Turkish, respectively); the $75 \%$ Syrian genotype being the heaviest. The foundation for the ICARDA flock was established in 1980 following which selection within the flock started. Therefore, the lack of difference between the $T$ and $\mathrm{S}$ lambs or the higher performance at weaning of the Syrian Awassi could have possibly resulted from the selection carried out in the Syrian genotypes. This implies that the Turkish Awassi should not be used to improve growth performance of Syrian flock. This could also point to the importance of genotype by environment interaction that needs to be considered when introducing genotypes in improvement programs, as not all genotypes perform equally in all environments (Steinheim et al., 2008). For instance, Hakan \& Mehmet (2013) reported the performance in terms of lamb growth and milk production of Awassi in Central Anatolian region of Turkey to be higher than our reports, this lends support to the previous statement about $\mathrm{G}^{*} \mathrm{E}$ interaction.

\subsection{Milk production performance}

There were no significant differences between the genetic groups for both lactation length and lactation milk yield (Table 3). However, daily milk yield was higher $(p<0.05)$ for the $75 \%$ Syrian genotype $(0.89 \pm 0.04 \mathrm{~kg} / \mathrm{day})$. This is again interesting because the Turkish Awassi were, as has been alluded to, introduced to improve the performance of the Syrian lines; however, the results seem to indicate otherwise.

In a similar study that considered data for years 2003-2005 of the same flock, Iñiguez \& Hilali (2009) reported that the Turkish ewes tended to have higher milk yield and prolonged milking length, compared to TS and S ewes. Average milk yield of TS and $\mathrm{T}$ ewes were $12 \%$ and $30 \%$ higher, respectively, than $\mathrm{S}$ ewes. Similarly, milking lengths of TS and T ewes were $7 \%$ and $22 \%$ higher, respectively, than $\mathrm{S}$ ewes. However, only the $\mathrm{T}$ ewes differed significantly in overall performance from the $\mathrm{S}$ and TS animals. This is contrary to our results and could possibly be due to two reasons. First, it could be related to differences in the data 
Table 3: Least squares means ( $\pm \mathrm{SE}$ ) for effects of year, genetic group and parity of ewe on lactation length, lactation milk yield and daily milk yield

\begin{tabular}{|c|c|c|c|}
\hline Effect and level & $\begin{array}{l}\text { Lactation } \\
\text { length } \\
\text { (days) }\end{array}$ & $\begin{array}{c}\text { Lactation } \\
\text { milk yield } \\
(\mathrm{kg})\end{array}$ & $\begin{array}{l}\text { Daily milk } \\
\text { yield } \\
\text { (kg/day) }\end{array}$ \\
\hline $\mathrm{N}$ & 1300 & 1241 & 1300 \\
\hline Overall & $100 \pm 2.0$ & $91 \pm 2.5$ & $0.84 \pm 0.02$ \\
\hline Year & $* *$ & $* *$ & $* *$ \\
\hline 2003 & $95 \pm 5.5$ & $89 \pm 6.7$ & $0.79 \pm 0.04$ \\
\hline 2004 & $86 \pm 4.1$ & $69 \pm 4.9$ & $0.71 \pm 0.03$ \\
\hline 2005 & $111 \pm 3.7$ & $109 \pm 4.5$ & $0.91 \pm 0.03$ \\
\hline 2006 & $103 \pm 3.5$ & $87 \pm 4.2$ & $0.81 \pm 0.02$ \\
\hline 2007 & $124 \pm 3.3$ & $113 \pm 4.0$ & $0.87 \pm 0.02$ \\
\hline 2008 & $77 \pm 3.1$ & $76 \pm 3.7$ & $0.92 \pm 0.02$ \\
\hline 2009 & $98 \pm 2.8$ & $86 \pm 3.3$ & $0.83 \pm 0.02$ \\
\hline 2010 & $100 \pm 3.2$ & $90 \pm 3.8$ & $0.84 \pm 0.02$ \\
\hline 2011 & $109 \pm 2.7$ & $101 \pm 3.3$ & $0.91 \pm 0.02$ \\
\hline Genetic group & NS & NS & * \\
\hline Syrian Awassi & $98 \pm 2.1$ & $87 \pm 2.8$ & $0.80 \pm 0.02^{\mathrm{a}}$ \\
\hline Turkish Awassi & $98 \pm 3.6$ & $99 \pm 6.2$ & $0.83 \pm 0.03^{\mathrm{ab}}$ \\
\hline $50 \%$ Cross & $101 \pm 2.5$ & $93 \pm 3.2$ & $0.86 \pm 0.02^{b}$ \\
\hline $75 \%$ Syrian & $105 \pm 5.3$ & $89 \pm 4.0$ & $0.89 \pm 0.04^{b}$ \\
\hline 75\% Turkish & $100 \pm 3.3$ & $88 \pm 4.3$ & $0.84 \pm 0.02^{\mathrm{ab}}$ \\
\hline Parity & NS & $* *$ & $* *$ \\
\hline 1 & $97 \pm 2.2$ & $81 \pm 2.7^{\mathrm{a}}$ & $0.75 \pm 0.02^{\mathrm{a}}$ \\
\hline 2 & $103 \pm 2.5$ & $91 \pm 3.1^{\mathrm{b}}$ & $0.83 \pm 0.02^{\mathrm{b}}$ \\
\hline 3 & $101 \pm 3.1$ & $96 \pm 3.7^{b}$ & $0.89 \pm 0.02^{\mathrm{c}}$ \\
\hline 4 & $101 \pm 3.6$ & $96 \pm 4.3^{\mathrm{b}}$ & $0.88 \pm 0.03^{\mathrm{c}}$ \\
\hline 5 & $100 \pm 3.1$ & $91 \pm 3.8^{\mathrm{b}}$ & $0.86 \pm 0.02 b^{c}$ \\
\hline
\end{tabular}

$*, p<0.05 ; * *, p<0.01 ; N S, p>0.05$, Least squares means with same superscript in the same column indicate non significance

size ( 3 vs 9 years' data). Here we used nine years data and we believe this gives a clear picture of the performance of the different genotypes compared to a 3 year dataset particularly under a semiarid environment where the effect of year is substantial on most recorded performances. Second, at the beginning there seemed to be a mating plan which involved different genotypes leading to mixture of crosses. This made it difficult to identify each genetic group and follow its performance unambiguously

Milk production performance of Awassi genotypes varied across different countries and production environments, ranging from $65.9 \mathrm{~kg}$ in 172 days lactation in Iraq to $506 \mathrm{~kg}$ in 214 days in Israel (Galal et al., 2008). Milk yield of unimproved Awassi ewes shows a wide variation among countries. An Awassi ewe produces $40-60 \mathrm{~kg}$ of milk per 150-day lactation period under traditional (extensive) production system (Degen \& Benjamin, 2003) and 70-80 $\mathrm{kg}$ under improved (intensive) production system at government research stations (Hailat, 2005). These levels do not include the suckling period when milk is left for lambs. The amount of suckling milk in traditional production system ranged between 68 and $90 \mathrm{~kg}$ during a period of 81-93 days (Hailat, 2005).These variations surely underline large genetic variability and present excellent opportunity to improve milk yield of the breed. It is important to also note that the milk production performance of improved Awassi breed is the highest after East Friesian (Galal et al., 2008). This is why the Awassi breed has been imported to different countries in Africa, Australia and South America to improve the milk and meat performance of local breeds via crossbreeding.

\subsection{Milk composition performance}

Lactation yields of milk constituents (fat, protein, lactose, total solids and solids-not fat) was significantly higher $(p<0.05)$ for the $50 \%$ and $75 \%$ Syrian crosses compared to the other crosses as well as the pure Awassi's, except for lactation protein yield (Table 4). There was no difference between the pure Syrian and Turkish Awassi genotypes. There are limited reports on milk composition of Awassi ewes. The percentages of milk dry matter, protein, and milk ash were $14.3 \%, 5.4 \%$, and $0.83 \%$, respectively. Milk protein percentage increased with advancement of lactation, reaching its highest values at the time of weaning (6.3\%) (Kridli et al., 2007). Compared to results from other breeds such as the Dorset (Sakul \& Boylan, 1992) and Egyptian Rahmani and Chios (Abd Allah et al., 2011), it is evident that the Awassi have higher values indicating an even added advantage of the breed for human nutrition as well as improved income for people keeping them, as sheep milk is often processed into cheese and other dairy products needing specific milk composition.

\subsection{Fixed effects}

\subsubsection{Growth performance}

Weight differences (birth weight, weaning weight, litter weight at birth and litter weight at weaning) between male and female were significant $(\mathrm{p}<0.01)$. In all cases, males were heavier than females. Sexual differences in growth traits could obviously be related to inherent physiological variations as has also been reported elsewhere (Belay \& Haile, 2009; Akhtar et al., 2012; Momoh et al., 2013).

Most of the growth traits showed an increasing trend over the years; the highest values for birth weight and litter weight at birth occurring during 2007. For weaning weight, the highest value was recorded in 2010. The increasing trend in growth performance over the years would indicate an improvement in the environment and/or genetic make-up of the flock. The influence of the year of birth on growth performance traits is well documented (Iñiguez \& Hilali, 2009; Momoh et al., 2013). 
Table 4 Least squares means ( \pm SE) for effects of genetic group, year and parity of ewe on milk constituents $(\mathrm{kg})$

\begin{tabular}{|c|c|c|c|c|c|}
\hline Effect and level & Lactation fat yield & $\begin{array}{l}\text { Lactation protein } \\
\text { yield }\end{array}$ & $\begin{array}{l}\text { Lactation lactose } \\
\text { yield }\end{array}$ & $\begin{array}{l}\text { Lactation total solids } \\
\text { yield }\end{array}$ & $\begin{array}{l}\text { Lactation solids-not } \\
\text { fat yield }\end{array}$ \\
\hline $\mathrm{N}$ & 1300 & 1300 & 1300 & 1300 & 1300 \\
\hline Overall & $5.24 \pm 0.17$ & $4.88 \pm 0.16$ & $4.47 \pm 0.14$ & $15.22 \pm 0.47$ & $9.99 \pm 0.31$ \\
\hline Year & $* *$ & $* *$ & $* *$ & $* *$ & ** \\
\hline 2003 & $4.70 \pm 0.42$ & $3.36 \pm 0.43$ & $4.78 \pm 0.35$ & $13.58 \pm 1.17$ & $8.89 \pm 0.77$ \\
\hline 2004 & $3.93 \pm 0.31$ & $3.51 \pm 0.32$ & $3.13 \pm 0.26$ & $11.08 \pm 0.88$ & $7.15 \pm 0.57$ \\
\hline 2005 & $6.00 \pm 0.29$ & $5.90 \pm 0.29$ & $5.19 \pm 0.24$ & $17.81 \pm 0.81$ & $11.86 \pm 0.53$ \\
\hline 2006 & $4.97 \pm 0.27$ & $4.87 \pm 0.27$ & $4.27 \pm 0.23$ & $14.79 \pm 0.77$ & $9.84 \pm 0.50$ \\
\hline 2007 & $6.76 \pm 0.26$ & $6.32 \pm 0.26$ & $5.55 \pm 0.22$ & $19.47 \pm 0.73$ & $12.72 \pm 0.47$ \\
\hline 2008 & $4.41 \pm 0.24$ & $4.23 \pm 0.24$ & $3.63 \pm 0.21$ & $12.80 \pm 0.68$ & $8.40 \pm 0.44$ \\
\hline 2009 & $5.41 \pm 0.22$ & $5.07 \pm 0.22$ & $4.15 \pm 0.18$ & $14.97 \pm 0.61$ & $9.56 \pm 0.40$ \\
\hline 2010 & $5.06 \pm 0.25$ & $5.02 \pm 0.25$ & $4.40 \pm 0.21$ & $15.07 \pm 0.69$ & $10.04 \pm 0.45$ \\
\hline 2011 & $5.99 \pm 0.22$ & $5.61 \pm 0.21$ & $5.11 \pm 0.18$ & $17.42 \pm 0.60$ & $11.44 \pm 0.39$ \\
\hline Genetic group & $*$ & NS & $*$ & $*$ & * \\
\hline Syrian Awassi & $4.95 \pm 0.18^{\mathrm{a}}$ & $4.61 \pm 0.17$ & $4.23 \pm 0.15^{\mathrm{a}}$ & $14.38 \pm 0.51^{\mathrm{a}}$ & $9.44 \pm 0.33^{\mathrm{a}}$ \\
\hline Turkish Awassi & $4.96 \pm 0.28^{\mathrm{ab}}$ & $4.44 \pm 0.28$ & $4.22 \pm 0.24^{\mathrm{a}}$ & $14.36 \pm 0.79^{\mathrm{ab}}$ & $9.44 \pm 0.52^{\text {ab }}$ \\
\hline $50 \%$ Cross & $5.38 \pm 0.21^{\mathrm{ab}}$ & $4.97 \pm 0.20$ & $4.64 \pm 0.17^{\mathrm{bc}}$ & $15.67 \pm 0.59^{\mathrm{ab}}$ & $10.29 \pm 0.38^{\mathrm{ab}}$ \\
\hline $75 \%$ Syrian & $5.85 \pm 0.40^{b}$ & $5.46 \pm 0.41$ & $4.86 \pm 0.34^{\mathrm{ac}}$ & $16.88 \pm 1.13^{b}$ & $11.03 \pm 0.74^{b}$ \\
\hline $75 \%$ Turkish & $5.08 \pm 0.26^{\mathrm{ab}}$ & $4.90 \pm 0.26$ & $4.38 \pm 0.22^{\mathrm{ac}}$ & $14.82 \pm 0.74^{\mathrm{ab}}$ & $9.74 \pm 0.48^{\mathrm{ab}}$ \\
\hline Parity & $* *$ & $* *$ & $* *$ & $* *$ & $* *$ \\
\hline 1 & $4.52 \pm 0.18^{\mathrm{a}}$ & $4.32 \pm 0.17^{\mathrm{a}}$ & $4.00 \pm 0.15^{\mathrm{a}}$ & $13.31 \pm 0.50^{\mathrm{a}}$ & $8.79 \pm 0.32^{\mathrm{a}}$ \\
\hline 2 & $5.15 \pm 0.20^{b}$ & $4.84 \pm 0.20^{b}$ & $4.47 \pm 0.17^{b}$ & $15.13 \pm 0.56^{\mathrm{b}}$ & $9.98 \pm 0.37^{b}$ \\
\hline 3 & $5.58 \pm 0.24^{b}$ & $5.10 \pm 0.24^{b}$ & $4.74 \pm 0.20^{b}$ & $16.06 \pm 0.67^{b}$ & $10.50 \pm 0.44^{b}$ \\
\hline 4 & $5.57 \pm 0.28^{b}$ & $5.12 \pm 0.28^{b}$ & $4.62 \pm 0.23^{b}$ & $16.07 \pm 0.78^{b}$ & $10.51 \pm 0.51^{\mathrm{b}}$ \\
\hline 5 & $5.40 \pm 0.25^{\mathrm{b}}$ & $4.99 \pm 0.24^{b}$ & $4.50 \pm 0.21^{b}$ & $15.55 \pm 0.69^{b}$ & $10.15 \pm 0.45^{\mathrm{b}}$ \\
\hline
\end{tabular}

$*, p<0.05 ; * *, p<0.01 ; N S, p>0.05$, Least squares means with same superscript in the same column indicate non significance

Parity of ewe had significant effect on all growth traits studied. Obviously, ewes in their first parity lambed and weaned lighter animals compared to subsequent parities. There was no clear trend in effect of parity except that lambs born in the third parity had slightly heavier weights.

\subsubsection{Milk production performance}

Lactation length, lactation milk yield and daily milk yield varied over the years with no consistent trend. The earlier years (2003 and 2004) as well as the years between 2008 and 2010 had lower values compared to 2007 and 2011, when higher values were recorded. Such inconsistent results could point to changes in management of the flock over the years or fluctuation in feed value during grazing periods.

Ewes in their first parity produced less milk from short lactations compared to other parities $(p<0.01)$. However, there were no differences between other parities. Trends in lactation milk yield over parities have been observed in a number of studies (Hatziminaoglou et al., 1990; Nuda et al., 2003). The general indication is that milk production performance increases with parity; the peak occurring, in most cases, during the third parity with a decline in later $(>5)$ parities.

\subsubsection{Milk composition performance}

Milk constituents (lactation fat, protein, lactose, total solids and solids-not fat yields) yields varied $(p<0.01)$ over the years but with no clear trend. Indeed, years 2007 and 2011 had higher values than the others. Parity strongly affected the contents of ewes' milk. The milk quantities of proteins, fat and lactose increased $(p<0.01)$ as the number of lactations advanced, with ewes in their $3^{\text {rd }}$ and $4^{\text {th }}$ parities having higher contents. Indeed, the constituent values declined during the fifth parity. Two possible causes have been advanced to explain the increase in milk constituents as the number of lactations progress (Sevi et al., 2000). Firstly, the increased body weight of the ewes with a greater number of lactations leads to a greater availability of body reserves for the synthesis of milk components. Secondly, the greater development of the udder glandular tissue as the number of lactations rise could also result in an increased synthesis of milk constituents. Some workers (Wohlt et al., 1981) have however not observed any differences in milk constituents between different parities. The conflicting results could possibility be due to differences in other factors like breed, feeding, number of lambs suckled, management practices and climatic conditions.

\section{Conclusions}

Inconsistencies in performance of the sheep flock over years 
could possibly be because of using sheep for different experiments resulting in lack of uniform, proper and systematic management. This warrants the need for strategic feeding and other management practices based on requirement and anticipated level of production.

This study points out that the performance of Turkish Awassi is not superior to that of their Syrian counterpart for all the traits considered within the environmental conditions of Syria. In addition to the fact that both environments in Turkey and Syria are not very different, the Turkish genotypes were introduced long ago and it is therefore believed that they have acclimatized to the Syrian environment, hence adaptation should not be considered a limiting factor to express their performances. We recommend that the Turkish Awassi should not be used as an improver breed for the Syrian genotype. Consequently, the different lines kept in the ICARDA flock (now moved to Terbol station in Lebanon) should be kept as one flock and within selection scheme designed. Comparisons of performances among the different genotypes indicated that the $75 \%$ Syrian inheritance are superior for most of the variables studied. Therefore, within flock selection could focus on retaining this genetic group to take advantage of the higher performance.

In general, the overall performance of the ICARDA Awassi flock has been better compared to that achieved for the same breed in other farms in the region. Therefore, improved rams produced from the breeding program could serve as improver for flocks maintained in different countries in the region, necessitating the development of sustainable delivery system of improved genetics.

\section{Acknowledgments}

This study is funded by ICARDA.

\section{Conflict of Interest}

The authors declare that the research was conducted in the absence of any commercial or financial relationships that could be construed as a potential conflict of interest.

\section{References}

Abd Allah M, Abass SF, Allam FM (2011) Factors affecting the milk yield and composition of Rahmani and Chios sheep. International Journal of Livestock Production 2 : 024-030.

Akhtar M, Javed K, Abdullah M, Ahmed N, Elzo MA (2012) Environmental factors affecting pre-weaning growth traits of Buchi sheep in Pakistan. Journal of Animal and Plant Sciences 22 : 529-536.

Belay B, Haile A (2009) Factors affecting growth performance of sheep under village management conditions in the south western part of Ethiopia. Livestock Research for Rural Development 21, Article \#189 http://www.lrrd.org/lrrd21/11/bela21189.htm.
Degen AA, Benjamin RW (2003) Milk intake and growth rate of Awassi lambs sucking ewes grazing on natural pasture in the semi-arid Negev. Animal Sciences 76: 455-460.

FAO (2015) The Second Report on the State of the World's Animal Genetic Resources for Food and Agriculture, edited by BD Scherf \& D Pilling. FAO Commission on Genetic Resources for Food and Agriculture Assessments, Rome available at http://www.fao.org/3/a-i4787e/index.html access on 25th April, 2017.

Galal S, Gürsoy O, Shaat I (2008) Awassi sheep as a genetic resource and efforts for their genetic improvement-A review. Small Ruminant Research 79 : 99-108.

Gürsoy O (2005) Small ruminant breeds of Turkey. In: Iñiguez L (Ed.), Characterization of Small Ruminant Breeds in West Asia and North Africa, I. West Asia. International Center for Agricultural Research in the Dry Areas (ICARDA), Aleppo, Syria, pp 239-416.

Gursoy O, Kirk K, Cebeci Z, Pollot GE (1995) Genetic evaluation of growth performance in Awassi sheep. In: Gabiña D (Ed.). Strategies for sheep and goat breeding. Zaragoza, Spain: CIHEAM, (Cahiers Options Méditerranéennes; n. 11) Pp 193-201.

Hailat N (2005) Small ruminant breeds of Jordan, In: Iniguez L (Ed.) Characterization of Small Ruminant Breeds in West Asia, North Africa, West Asia. ICARDA, Aleppo, Pp. 30-61.

Hakan ÜSTÜNER, Mehmet Mustafa OĞAN (2013) Main productive performance of Awassi sheep in the Central Anatolian Region of Turkey. Turkish Journal of Veterinary and Animal Sciences 37: 271-276.

Hatziminaoglou I, Geogordiudis A, Karalazos A (1990) Factors affecting milk yield and prolificacy of Karagouniko sheep in West Thessaly (Greece). Livestock Production Science 24:181-186.

Iñiguez L, Hilali M (2009) Evaluation of Awassi genotypes for improved milk production in Syria. Livestock Science 120: 232239.

Kassem R (2005) Small ruminant breeds of Syria. In: Iñiguez L (Ed.), Characterization of Small Ruminant Breeds in West Asia and North Africa, I. West Asia. International Center for Agricultural Research in the Dry Areas (ICARDA), Aleppo, Syria, Pp. 183-237.

Kridli RT, Abdullah YA, Shaker MM, Al-Smadi NM (2007) Reproductive performance and milk yield in Awassi ewes following crossbreeding. Small Ruminant Research 71: 103-108.

Milán MJ, Caja G, González-González R, Fernández-Pérez AM, Such X (2011) Structure and performance of Awassi and Assaf dairy sheep farms in northwestern Spain. Journal of Dairy Science 94: 771-784. 
Momoh OM, Rotimi EA, Dim NI (2013) Breed effect and nongenetic factors affecting growth performance of sheep in a semiarid region of Nigeria. Journal of Applied Biosciences 67: 53025307.

Nuda AM, Feligini G, Battacone NP, Paolo M, Giuseppe P (2003) Effects of lactation stage, parity, $\beta$-lactoglobulin genotype and milk SCC on whey protein composition in Sarda dairy ewes. Italian Journal of Animal Science 2: 29-39.

Sakul H, Boyland WJ (1992) Evaluation of US sheep breeds for milk production and milk composition. Small Ruminant Research 7: 195-201.

SAS (2002) Statistical analysis systems for mixed models. SAS Institute Inc., Cary, NC, USA.
Sevi A, Taibib L, Albenzioa M, Muscioa A, Annicchiarico G (2000) Effect of parity on milk yield, composition, somatic cell count, renneting parameters and bacteria counts of Comisana ewes. Small Ruminant Research 37: 99-107.

Steinheim G, Odegård J, Adnøy T, Klemetsdal G (2008) Genotype by environment interaction for lamb weaning weight in two Norwegian sheep breeds. Journal of Animal Sciences $86: 33$ 39.

Talafha AQ, Ababneh MM (2011) Awassi sheep reproduction and milk production: review. Tropical Animal Health and Production 43: 1319-1326.

Wohlt JE, Kleyn DH, Vandernoot GW, Selfridge DJ, Novotney CA (1981) Effect of stage of lactation, age of ewe, sibling status and sex of lamb on gross and minor constituents of Dorset ewe milk. Journal of Dairy Science 64: 2175-2184. 